\title{
Tramelling The Illegal Wildlife Trading: A Comparative Legislative Analysis of China and India
}

\author{
Sandeep Kumar Mohanty ${ }^{1 *}$, Soumya Prakash Patra ${ }^{2}$ \\ ${ }^{\text {}, ~ I n d i a n ~ I n s t i t u t e ~ o f ~ T e c h n o l o g y ~ K h a r a g p u r, ~ K h a r a g p u r, ~ I n d i a ~}$ \\ 2, Department of Commerce and Management, St. Xavier University, Kolkata, India \\ *E-mail: mohanty.sandeep27@gmail.com
}

Submitted: 06/08/2021

\begin{tabular}{l}
\hline Info Artikel \\
\hline Keywords: \\
Illegal Wildlife Trade; \\
CITES; Transnational \\
Crimes; Endangered \\
Species. \\
\\
DOI: \\
$10.47268 /$ sasi.v27i4.597 \\
\hline
\end{tabular}

Revised: $30 / 10 / 2021$

Published: $31 / 12 / 2021$

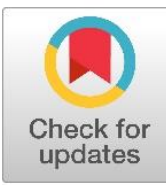

Allegal wildlife trade is one of the major transnational crimes. Transnational Crime, by its very nature, is problematic as it surpasses national jurisdictions, as well as the parameters of information systems and law enforcement agencies. Illegal wildlife trade networks increasingly operate like global multinational businesses, connecting local markets to the global markets through complex and interlinked networks. Against this background, CITES was entered into, multinational environmental agreement to which 183 nations are parties to it and India, being a member of CITES, in compliance with the guidelines, has enacted an umbrella of 8 legislation for the protection of wildlife in India. But despite this austere legislation, India is progressively becoming a hub of illegal wildlife trade. The illegal laundering of wild-caught animals via legal pathways is subject to increased scrutiny. It appears that illegal wildlife traders are rampantly using other covert methods to smuggle these animals into the territories of target consumer countries, such as China. Once they enter into the jurisdiction of destination countries that permit legal trade in this species, it becomes arduous for the relevant enforcement agencies to distinguish between the wild-caught and captive-bred animals. The author undertakes to carry out a comparative analysis of the existing legislation of China concerning India to understand whether the legislation is robust enough for the protection of the wildlife and how the enforcement mechanism can be strengthened for the advancement of the endangered species.

\section{A. INTRODUCTION}

Asia is the heart of the international illegal wildlife trade. The significant-high purchasing power of many big economies in the region is rampantly increasing the demand for rare endangered species as pets, medicines and food. Fuelled by criminality and corruption, the proceeds average $\$ 23$ billion a year and threaten some of the world's most iconic species. ${ }^{1}$ The illicit wildlife trade includes trafficking in animal parts such as elephant ivory for decorative

\footnotetext{
${ }^{1}$ Africa Wildlife Foundation. 2015 World Wildlife Day Highlights Severity of Wildlife Crime. See https://www.awf.org/news/world-wildlifeday-highlights-severity-wildlife-crime (Last visited on 20th February 2020).
}

$$
\text { 549|SASI Vo1. } 27 \text { Issue.4, October - December } 2021
$$


objects, and rhino horns, tiger bones and genitals, leopard pelts and paws, and bear paws and gallbladders for use in traditional African and Asian medicines ${ }^{2}$ and pelts from various animals for clothing, rugs and wall-hangings. ${ }^{3}$

Plant species, rare and common, are poached to meet the consumer demand for holistic medicines and yard decorations. ${ }^{4}$ Certain marine species considered delicacies such as abalone, shark-fin and beluga caviar are illegally over-fished. ${ }^{5}$ Rampant demands from big economies like China, the US and the EU for wildlife animals drive the whole cross-border crime league of wildlife trade. And the relentless demand for endangered wildlife resulted in many species of the whole region near extinction.

China is a major destination country for wildlife products, with its consumption demanding from Tiger bones to endangered snakes and arthropods. And the supple legislation of China is not enough to restrict the illegal wildlife trade activities in the Chinese jurisdiction. The versatile Chinese legislation has its effects across the borders also. India is sharing a porous border with China and is either the source country or the international passage for the illegal wildlife trade. The author intends to analyze the specific legislation of China and India about illegal wildlife trade, tackle the gaps in the legislation, and analyze the impact of one's domestic legislation affecting the wildlife protection mechanism of the border-sharing countries.

\section{B. RESULTS AND DISCUSSION}

\section{Legislative Framework Of China On Illegal Wildlife Trade}

The first law to protect China's wildlife animals is the People's Republic of China on the Protection of Wildlife, 1989 (hereinafter referred to as PRCPOW Act). ${ }^{6}$ The law contains five chapters and 59 articles. These articles cover provisions on the scope of protection, protection and management mechanisms, wildlife ownership and penalties. The law addresses issues such as wildlife farming that had been neglected in past policies. Since 1988, the PRCPOW Act has been revised twice to include an article on the management of hunting grounds for foreigners. The major revision of the law came in 2016, which made a significant overhaul of the law, and it came into effect on 1st January 2017. The PRCPOW Act has two-fold advantages. Firstly, protect and rescue rare and endangered wildlife, regulate the use of wildlife resources and preserve biodiversity. Secondly, it aims to promote ecological balance through wildlife management and protection. ${ }^{7}$ The author is only dealing with the vital and significant provisions of the PRCPOW Act.

a. Significant Provisions Of The Prcpow Act

\section{1) Ownership}

The state shall own wildlife resources. According to the law, the state safeguards the lawful rights and interests of organizations and individuals engaged in the protection of wildlife and related activities, including scientific research and captive breeding. ${ }^{8}$ Thereby meaning ownership of all wildlife resources belong to the state and captive breeding is still allowed for

2 Reboredo, F. (2013). Socio-economic, environmental, and governance impacts of illegal logging. Environment Systems and Decisions, 33(2), 295-304.

3 Illegal bird trade, Indian Bird Conservation Network, By Abrar Ahmed, 2015.

4 Newton, D. J., \& Chan, J. (1998). South Africa's trade in southern African Succulent Plants. Traffic east/southern Africa.

5 Challender, D. W., Harrop, S. R., \& MacMillan, D. C. (2015). Understanding markets to conserve tradethreatened species in CITES. Biological Conservation, 187, 249-259.

6 Adopted at the Fourth Meeting of the Standing Committee of the Seventh National People's Congress and promulgated by Order No. 9 of the President of the People's Republic of China on November 8, 1988, and effective as of March 1, 1989.

7 Nagle, J. C. (1996). Why Chinese Wildlife Disappears as CITES Spreads. Geo. Int'l Envtl. L. Rev., 9, 435.

8 See Article 3 of Law of the People's Republic of China on the Protection of Wildlife, 1989.

$$
\text { 550|S A I Vol. } 27 \text { Issue.4, October - December } 2021
$$


scientific purpose. The revised law also bought in that the state will no longer award "outstanding achievements in the domestication and breeding of wildlife," as provided in the old law. ${ }^{9}$

\section{2) Wildlife Protection}

Chapter 2 of the PRCPOW Act casts responsibility on the state for the protection of wildlife. There is a bare restriction on construction projects in nature reserves. As indicated by the current law, sites and routes for development undertakings like air terminals, rail lines, streets, waterworks, and so forth, shall avoid nature reserves and wildlife movement paths. At the point when it isn't plausible to stay away from the nature stores and relocation ways, the framework ventures will assemble passageways for wildlife and transitory fish facilities and execute different measures to mitigate the unfriendly effect on wildlife ${ }^{10}$. Consequently, we can see that there is a severe command on the state in development the infrastructure projects, which upsets the normal territory of the natural life.

\section{3) Administration Of Wildlife}

Under Article 24 of the amended PRCPOW Act, the definition of hunting methods was extended, consequently including poisons, explosives, electronic stun, electronic snare gadgets, catches, leg-hold traps, stopgap weapons, and so forth Guerrilla-style chasing, evening chasing with lights, and chasing by destroying nests or utilizing fire, smoke, or nets were likewise denied. Hostage reproducing of wildlife for business and logical objects is as yet permitted, up to a permit is acquired from provincial-level government authorities under Article 25 of the PRCPOW Act. The amended PRCPOW Act requires hostage rearing of wildlife under national protection to "be beneficial to the protection of the species and its scientific research" and nondamaging of the species in nature. It will likewise be guaranteed that there is essential development space and states of living, reproducing, wellbeing, and sterilization for wildlife in understanding to their practices, ensure the concerned party has sites, facilities, and technologies appropriate to the rearing reason, types and improvement scale, and agree with important specialized principles and illness anticipation necessities ${ }^{11}$.

\section{4) Offences}

The amended PRCPOW Act precludes the sale, purchase, or utilization of uncommon or close extinction wild animals and their items under special protection. ${ }^{12}$ Be that as it may, exemptions are made for specific purposes, including scientific research on captive breeding and public displays or exhibitions including wild animals. Exceptional consent should be acquired from the public authorities, and a special mark should be gotten and used to ensure the tracking.

b. Loopholes In The Legislation

1) Licensing system under the new legislation allows commercial breeding, utilization and trading in species under special state protection.

2) The newly amended law authorizes a captive breeding permit system that allows commercial breeding for the purposes of trade and utilization of endangered species.

3) The legislation allows the sale and utilization of endangered species for the purposes of "public exhibition or performance" and does not explicitly specify which permits allowing trade for such purposes would be antagonistic to captive breeding specimens.

4) Under the newly amended law, provincial-level government departments were given maximum responsibility for the implementation of the Wildlife Protection Law but

9 See Article 4 of Law of the People's Republic of China on the Protection of Wildlife, 1989

10 See Article 13 of Law of the People's Republic of China on the Protection of Wildlife, 1989.

$11 \mathrm{https}: / / \mathrm{www} \cdot$ loc.gov/law/foreign-news/article/china-new-wildlife-protection-law/ (Last visited on $20^{\text {th }}$ February 2020).

12 See Article 31 of Law of the People's Republic of China on the Protection of Wildlife, 1989. 
enumerated inadequate requirements relating to supervisory, planning or accountability mechanisms. Hence this is a significant loophole, which could be exploited to the injury of wildlife and hinders China's ability to report on obligations cast under the Convention on International Trade in Endangered Species of Wild Fauna and Flora (hereinafter referred to as "CITES"). And lastly, the lack of proper infrastructures will lead to more chaos than before.

5) The existing law and regulations do not specifically prohibit the possession of illegally sourced endangered wildlife products, which restricts the enforcement to combat the illegal wildlife trade.

\section{Legislative Framework Of India On Illegal Wildlife Trade}

a. Wildlife Protection During The Pre-Independence Period

In the pre-independence time frame, there were a couple of enactments which were authorized to secure the wild life. Few of them were: The Cattle Trespass Act, 1871; The Elephants Preservation Act, 1879; Section 428 and 429 of Indian Penal Code, 1860; wild Birds and Animals Protection Act, 1912, and The Indian Forest Act, 1927.

\section{b. Wildlife Protection During The Post-Independence Period}

The Post-independence era witnessed a lot of changes in the policies and attitudes of the Governments with respect to environmental and wildlife protection. There were many enactments relating to the Forest, Environment, Water, Air and Bio-Diversity. All these statues directly or indirectly gave provisions to the protection of wildlife. The Wild Life (Protection) Act, 1972 (hereinafter referred to as WLPA Act) is the first legislation that was dedicatedly ratified for the security of wildlife in India. The Parliament also passed two other legislation, namely Forest Conservation Act, 1980 and Biological Diversity Act, 2002, in due time. The Central Government left no stone unturned in formulating various rules and policy like The Wild Life (Transactions and Taxidermy) Rules, 1973; The Wild Life (Stock Declaration) Central Rules, 1973; The Wildlife (Protection) Licensing (Additional Matters for Consideration) Rules, 1983; The Wild Life (Protection) Rules, 1995; The Wild Life (Specified Plants - Conditions for Possession by Licensee) Rules, 1995; Forest (Conservation) Rules, 1981; National Forest Policy, 1988; Besides these, legislations on Air (Prevention and Control of Pollution) Act 1981, Water (Prevention and Control of Pollution) Act 1974, Environment (Protection) Act 1986, and so on also encompasses the provisions to protect the wildlife.

In spite of the existence of a number of legislations, the working of the WLPA Act has not been up to yardstick, and hence, in the year 1986, the Act was suitably amended. Under the previous Act, the trade and commerce in wild animals were permissible within the country. Smuggling animal skins, flesh and articles internationally for garnering huge profit were rampant. Hence, it turn out to be indispensable to restrict the trading of wild animals in certain categories. By virtue of the 1986 amendment, it was restricted that "no one will be allowed to carry on trade in wild animals specified in stated Schedules I and II of the Act." A strict restriction was placed on the trading of ivory.

As the past amendment was not abundant for limiting the wildlife trade in India and widespread poaching exercises and unlawful exchange creature articles, the wildlife populace in India has significantly diminished. As a result, in the year 1991 WLPA Act was further amended on the basis of recommendations of the Indian Wildlife Board and the Ministry of Environment and Forest. The 1991 Amendment Act restricts the hunting of all wild animals except vermin. Certain exceptions, such as the protection of life and property, education, research, scientific management, captive breeding, and hunting of wild animals, were permitted. Necessary vaccination was provided in national parks and sanctuaries to the animals for controlling the death rate on account of communicable diseases. Further, it was stated that 
without declaring the rights of aboriginal people in the forests, no zone could be declared as a national park or a sanctuary.

The 1991 Amendment Act perceived the zoos in the protection of wildlife in the nation, and consequently it was ordered that the Central Zoo Authority will screen the administration of zoos set up under the Amendment Act. Further, based on CITES, the assortment of endangered species and plants has been precluded aside from the conventional bonafide use by tribal people. Similarly, the massive poaching activities of African elephants became a concerning factor for the member of CITES, furthermore, consequently, the import and export of African ivory for business reasons for existing was prohibited. On the premise CITES India likewise denied the exchanging of ivory for securing Indian elephants through the 1991 Amendment Act of. Furthermore, the Act prohibits snake venom collection for producing lifesaving drugs from snakes like Cobra and Russell's viper. ${ }^{13}$ In 1973, a central government supported scheme, "Project Tiger," 14 was launched for ensuring and saving the populace of tigers in India. Similarly, in 1991-92, The "Project Elephant" ${ }^{15}$ was initiated, for confirming their long-term survival.

\section{c. Wildlife Protection Under The Constitution Of India}

A citizen has a Fundamental Right to carry on trade, business or occupation under Article 19(1) (g) of the Constitution of India. ${ }^{16}$ The right to freedom, as revered under Article 19 of the constitution however basic yet is certainly not a absolute right and is consistently dependent upon reasonable limitations, which might be forced in the bigger interest of people in general. The destruction or depletion of plants and animals would create serious ecological imbalances prejudicing human life. No one can be given the right to endanger human life as that would violate Article 21 of the Constitution.

The Indian Constitution makes adequate arrangements to secure the wildlife with its region. In spite of the fact that there are many inferred arrangements on wildlife security in the constitution like Art.21, Union List, State List and Concurrent List. The crucial articles which explicitly secure the untamed life are Art.48-An and Art. 51-A(g). Article 48-A says that the state will Endeavor to protect and improve the climate and shield the nation's forest and wildlife while Art. 51 A (g) forces a principal obligation on each resident of India to ensure and improve the climate and have sympathy for living animals.

\section{d. Significant Provision Of Wlpa Act}

The WLPA Act gives security to listed species of plants and animals and makes a web of biologically significant ensured regions for them. The Act comprises of 66 Sections and VI Schedules separated into nine Chapters. The Act went through numerous alterations, which we have discussed before exhaustively. Inevitable changes have been made by the Wildlife (Protection) Amendment Act, 2002, and another part has been intertwined as Chapter VI-A to deal with the surrender of property got from unlawful pursuing and trade. Further, this amendment Act likewise presented the idea of co-usable administration through conservation reserve management committees and community reserve committees. The latest amendment came in the year 2006, whereby a new Chapter IVB was also introduced for the establishment of the National Tiger Conservation Authority and notification of Tiger Reserves. Prior to this amendment, Tiger Reserves were not defined under the law but were only administrative designations to enable funding under Project Tiger. The Wildlife Crime Control Bureau (hereinafter referred to as WCCB) was constituted vide the 2006 amendment to monitor and

13 See Schedule 1 of Wildlife (Protection) Act, 1994

14 Tigers in the twilight; India., The Economist (US), 2006.

15 Johnsingh, A. J. T., \& Williams, A. C. (1999). Elephant corridors in India: lessons for other elephant range countries. Oryx, 33(3), 210-214.

16 See Article 19 of The Constitution Of India, 1950

$$
\text { 553|SASI Vo1. } 27 \text { Issue.4, October - December } 2021
$$


control the illegal trade in wildlife products. As it is not feasible to discuss each section within the limit of this paper, the author intends to discuss only the major provision of the WLPA and the analysis of those clauses.

\section{1) Jurisdiction Of The Wlpa Act}

WLPA Act has been accepted and adopted by all the states. ${ }^{17}$ This is the principal extensive enactment identifying with the security of wildlife that the Parliament passed, and it was stated by the President on ninth September 1972 and came to be known as The Wild Life (Protection) Act, 1972 (53 of 1972).

\section{2) Definition of The Term "Wildlife"}

Section 2(37) of the WLPA Act characterizes wildlife as it incorporates any animal, honey bee, crustaceans, butterflies, fish and moths, amphibian or land vegetation that structures part of any natural surroundings. So the significance of the natural life in this Act is expansive and incorporates a wide range of flora and fauna.

3) Authorities Under The Wlpa Act

According to Section 3 of the Act, the Central Government may choose a Director of Wildlife Preservation, Assistant Directors of Wildlife Preservation and such different officials and representatives as might be necessary. According to Section 4, the State Government may choose Chief Wildlife Warden, Wildlife Warden, Honorary Wildlife Wardens and different officials and representatives as might be important.

\section{4) Constitution of The State Board For Wildlife}

Under Section 6, the State Government is mandated to constitute a Wildlife Advisory Board. The Chief Minister of the State shall head the Board as the Chairperson and the Ministerin-charge of Forests and Wild Life as the Vice-Chairperson. The State Chief Wild Life Warden will be the Member-Secretary. Other Members include three members of the State Legislature, three from non-governmental organizations, ten from amongst the eminent conservationists, environmentalists, ecologists of which at least two will be from the Scheduled Tribes and others representing the Secretaries Head of the Government Department concerned and representatives from various organizations. ${ }^{18}$

\section{5) Duties of The State Board For Wildlife}

The State Board for Wildlife was mainly constituted to advise the state government in the following matters. ${ }^{19}$

a) Selection and the management of regions to be announced as protected areas;

b) Formulation of the policy for protection and preservation of wildlife and specified plants;

c) Matters identifying with the alteration of any schedule;

d) Measures to be taken for orchestrating the requirements of the tribal and other dwellers of the forests with the protection and conservation of wildlife;

e) Any different issue associated with the protection of wildlife might be alluded to it by the state government.

6) Hunting of The Wildlife Animals

Chapter III arrangements with the hunting of wild creatures. Section 2(16(a)(b)(c)) characterizes the word hunting which incorporates; capturing, killing, harming, catching, and catching of any wild animal and each try to do in that capacity; driving any wild creature for

\footnotetext{
${ }_{17}$ See Sec 1 of the Wildlife (Protection) Act, 1972.

18 See Sec 6 of the Wildlife (Protection) Act, 1972.

19 See Sec 8 of the Wildlife (Protection) Act, 1972.
}

$$
\text { 554|SASI Vo1. } 27 \text { Issue.4, October- December } 2021
$$


any of purposes showed in sub-provision; harming or annihilating or taking any piece of the body of any such animal, or by virtue of wild birds or reptiles, hurting the eggs of such birds or reptiles, or disturbing the eggs or homes of such birds or reptiles; Section 9 of the WLPA Act precludes hunting of any wild creature indicated in expressed Schedules I, II, III, and IV of the Act, besides as given under segment 11 and 12 .

However, The Chief Wildlife Warden may allow the hunting of wild animals in specific circumstances. Initially, when The Chief Wildlife Warden is satisfied that any wild creature indicated in the expressed Schedule I has gotten perilous to human existence or is impaired or sick as to be past recuperation, by request recorded in writing and referencing the reasons, consequently, license any individual to chase such creature or cause the creature to be pursued; Secondly, The Chief Wildlife Warden or the approved official may, in the event that he is satisfied that any wild creature determined in Schedule. II or III or IV has gotten hazardous to human existence or to property or then again is so handicapped or diseased as to be past recuperation, by request recorded as a hard copy and expressing the reasons, in this way, license any individual to chase such creature or cause such creature to be pursued. Thirdly, the killing or injuring in good faith of any wild animal in defence of oneself or of any other person shall not be an offense; Given that nothing in this sub-segment will excuse any individual who, when such defence gets necessary, was submitting any act in contradiction of any arrangement of this Act or any standard or request made thereunder. ${ }^{20}$ The Chief Wildlife Warden may permit by a request expressing the reasons, to any individual and on making payment of such fee, it will entitle the holder of such grant to hunt for the purpose of education, scientific research, scientific management, specimen collection and collecting snake venom for the manufacture of life-saving drugs.

\section{7) Protection of Specified Plants}

Chapter III-A specifically deals with the protection of specified plants which was inserted through the 1991 amendment act. Sec. 17A of the WLPA prohibits picking, uprooting, damaging, destroying, acquiring and collecting etc., of specified plants. Notwithstanding, it will not forestall an individual from a scheduled tribe, subject to the arrangements of Chapter IV, from picking, gathering or having in the locale where he stays any predefined plant for his genuine individual use. The Chief Wild Life Warden may, with authorization of the State Government, license any individual to pick, remove, obtain or gather from a timberland land or the region indicated under area 17A subject to such conditions as might be determined in that, any predefined plant with the end goal of training, logical examination, assortment, protection and show in a herbarium of any logical organizations, or engendering by an individual or an establishment endorsed by the Central Government in such manner. ${ }^{21}$

\section{8) Sanctuary}

The word sanctuary is defined in Section 2(26), which means an area declared as a sanctuary by notification under the provisions of Chapter IV of the WLPA and also includes a deemed sanctuary under Section 66(4). Under Section 18, whenever the state government intends to constitute any area other than area comprised with any reserve forest or the territorial waters as a "sanctuary" if it considers that such area is of adequate ecological, faunal, floral, geomorphologic, natural or zoological significance, for the purpose of protecting, propagating or developing wildlife or its environment then it may be declared through a gazette notification. The Chief Wildlife Warden, on an application, made an award to any individual a license to enter or live in a safe-haven for the reasons like examination or investigation of wildlife, photography, scientific research, tourism and transaction of lawful business with any person in the sanctuary. The right to enter into the sanctuary is not absolute rather, and it has to be

20 See Sec 11 of the Wildlife (Protection) Act, 1972.
21 See Sec 17-B of the Wildlife (Protection) Act, 1972 .

555 |S A S V V 1. 27 Is su e.4, October-December 2021 
sanctioned by the Chief Wild Life Warden and on such terms and conditions and on payment of the fees as may be prescribed.

9) National Parks

National Parks is dealt with under Section 35 of the WLPA. For protection, proliferation or development of wildlife, the state government may by notice proclaim that a region, by reason of its environmental, faunal, flower, geomorphologic or zoological relationship of significance, should have been comprised as a "National Park." Once it is chosen to announce a National Park, no modification of the limits can be made besides on the legislature's resolution. The accompanying exercises are rigorously disallowed:

a) Destroying, investigating or eliminating any wildlife,

b) Destroying, harming the territory of any wildlife,

c) Deprive any wildlife of its environment,

d) Grazing of any animals.

The explanation of Section 35 seeks to amend Section 35 of the WLPA to provide for final notification of those areas where the rights of the people have been extinguished, and the land has become vested in the State Government without going through the process of the settlement required under section 35(3) of the WLPA. A provision is also being made not to alter the boundaries of National Parks without the recommendations of the National Board for Wild Life. The destruction, removal and exploitation of wildlife from the National Park have been prohibited. The forest produce, if removed, are to be utilized only for the bonafide personal use of the local tribal people. It is also proposed to prohibit the removal of forest produce for commercial purposes.

\section{0) Central Zoo Authority And Recognition Of Zoos}

The Central Zoo Authority got its recognition through the Amendment Act 44 of 1991, which resulted in the insertion of Chapter IV-A. The Central Government will constitute the Central Zoo Authority, comprising of a chairperson, ten individuals and a member secretary. They will hold office for a time of three years. The Central Zoo Authority will play out the accompanying capacities under Section 38-C of the WLPA.

a) Declaring the minimum standards or norms for housing, up keeping and veterinary care of the animals to be kept in a zoo;

b) Evaluating and assessing the zoos with w.r.t standards or the norms that are laid down.

c) Recognition and de-recognition of the zoos.

d) Captive breeding of the endangered species of wild animals and assigning responsibility in this regard to a zoo.

e) Synchronizing the process of acquisition, exchange and loaning of animals for breeding purposes.

f) Maintenance of stud-books of endangered species of wild animals bred in captivity.

g) Identify the priorities and themes with regard to the display of captive animals in a zoo;

h) Coordinating the research activities in captive reproducing and educational projects for the motivations behind zoos;

i) Providing the specialized and other fundamental help to zoos for the viable administration and advancement on scientific lines.

j) Perform such different functions as might be important to complete the purposes behind the WLPA as to zoos.

11) Trade or Commerce In Wild Animals, Animal Articles And Trophies 
The term trophy means the whole or any piece of any captive animal or wild animal, other than vermin, which has been kept or secured utilizing any means, whether or not fake or regular, and fuses carpets, skins, and instances of such creatures mounted in whole or somewhat through a collaboration of taxidermy, and prong, horn, rhinoceros' horn, feather, nail, tooth, musk, eggs, and homes. An uncured trophy means the whole or any piece of any hostage animal, other than vermin, which has not gone through a pattern of taxidermy and fuses recently butchered untamed life ambergris, musk and other animal things ${ }^{22}$.

Section 39 of the WLPA reports that every wild creature other than vermin, which is sought after or kept or duplicated in detainment or found dead or killed unintentionally, will be the property of the State Government. Additionally, creature articles, prize or uncured prize, meat got from any wild animal, ivory imported to India, the article delivered utilizing such ivory, vehicle vessel weapon, trap or device that has used for presenting an offense and has been held onto will be the property of the state government. If any of the above is found in the sanctuary or a National Park reported by the Central Government, by then it will be the property of the Central Government.

The language of Section 39(d) makes it very clear that when it is found that a vehicle has been used for committing an offense and has been seized under the Act's provisions, the same shall be the property of the Government. Thus, so long as the competent court of law does not find the vehicle had in fact been used for the purpose of the commission of the offense, the vehicle does not become the property of the State Government.

\section{2) Prevention And Detection of Offences}

Section 50 of Chapter VI of the WLPA gives the power of entry, search, capture and confinement on the Director or some other official approved by him or the central natural life warden or official approved by him or any Police Officer, not underneath the position of Subinspector. Official not beneath the position of Assistant Director of Wildlife Preservation or Wildlife Warden will have the powers to issue a search warrant, to authorize the participation of witnesses, to propel the disclosure and creation of reports and material items and to get and record evidence.

\section{3) Cognizance of Offences}

No court will take cognizance of any offense against the WLPA besides on a grievance by: The Director of wildlife protection or some other official approved for this benefit by the Central Government or; The Chief Wildlife Warden or some other official approved by the State Government; or, any individual who has given notice of not less than 60 days, in the way endorsed, of the supposed offense and of his goal to submit a complaint to the Central Government or the State Government or the official approved as afore-mentioned. This seeks to amend Section 55 of WLPA so as to empower the Member-Secretary of the Central Zoo Authority, Member-Secretary Tiger Conservation Authority, Director of concerned Tiger reserve and officer in charge of the zoo to file a complaint in matters relating to violation of provisions contained in Chapter IV-A of the Act relating to establishment, recognition and management of zoos.

\section{4) Punishments}

Section 51 of the WLPA spells out the penalties for the violation of its provisions. Penalties vary depending on the Schedule of the animals to which the offense relates; the area to which the offense relates like the National Park, sanctuary, tiger reserve, core area of tiger reserve; the nature of the offense, which includes hunting, altering the boundaries, other offense and the punishment for the repeat offender.

\footnotetext{
${ }^{22}$ See Sec 2(32) of the Wildlife (Protection) Act, 1972. 557|SASI Vol. 27 Issue.4, October - December 2021
} 


\section{5) Seizure of Property Derived From Illegal Hunting And Trade}

A fresh chapter, Chapter VI-A, had been brought-in by the Wildlife (Protection) (Amendment) Act of 2002. As indicated by this new part, if any individual or partner of people or trust obtains property from illicit chasing or exchange of untamed life, it will be relinquished to the State Government by the capable authority. Such property can be relinquished in the wake of making every single vital step (request, examination or overview in regard of any individual, place, property, records, foundation, and so on) and in the wake of following and distinguishing any such property. During the examination and continuing of relinquish the property, if the competent authority tracks down that only a part of the gained property is demonstrated unlawful, the authority will make orders, offering a chance to the person affected, to pay a fine equivalent to the market worth of such piece of the property in lieu of relinquishment.

e. Loopholes In The Legislation

1) The WLPA does not take any special cognizance of Regional Red Lists produced by the Nations or Organizations and adopts a short-sighted approach to conservation of species that are migratory or trafficked animals in transit.

2) Internationally traded species protection is not reflected in the WLPA, which is mainly aimed at the protection of local indigenous species and has no provisions dealing with alien species that may be trafficked through India.

3) CITES Appendixes provide an exhaustive taxonomical list of species that cannot be traded internationally. The WLPA fails to make accommodations to impose punitive measures for trade in these species locally.

4) The provision for self-defense mechanism as provided under Section 11(2) of the WLPA is often abused and easily claimed while hunting wildlife.

5) The WLPA is silent on the procedure for ethical capture, handling, and releasing endangered snakes in their natural habitat.

\section{Findings}

China and India form the golden gateway for the illegal wildlife trade of Asia. With the countries sharing a porous border with each other, things become increasingly onerous for the enforcement agencies to keep the illegal wildlife trade under control. In addition to the existing trans-border issues, the countries' pliable wildlife protection legislation provides a suitable arena for committing wildlife crimes. An overview of the legislative framework of China and India gives a clear picture of the loopholes in the existing legal framework. The comparative analysis will show the glaring picture of the difference between the nations' international obligations for wildlife protection and domestic legislation.

1) None of the legislations implement the CITES list of protected species as a whole, leading to a condition where the import/Export of those species which are not covered under the domestic legislation cannot be protected.

2) As China is the biggest destination country and allows captive breeding and commercial trade, and utilization of the protected wildlife, it leads to increasing poaching activity in the neighboring country India. This wildlife is then passed off as captive breed animals across borders, making them legal under the Chinese legislation.

3) Both the legislations do not lay down the procedure for the ethical capture and handling of endangered species for scientific and research purposes.

4) Apart from these, there is no provision in any of the legislative frameworks for the exchange of taxonomical data of the protected species with the neighboring country for a better implementation of the Wildlife Protection Legislations. 
Apart from the lacunas in the current legislation, wildlife protection mechanisms of these nations are plagued by administrative incompetency also. Even though each has its own set of issues to deal with, a set pattern can be found in the enforcement laxities of both nations. They are enumerated as below:

1) The feeble institutional standing of wildlife protection departments is most clearly indicated by their meager budget allocation, inadequate manpower planning and capacity building as there is no substantial budget allocation for wildlife protection.

2) There is a complete lack of coordination between the enforcement agencies' different agencies having no standard of operating procedure.

3) The dwindling judicial mindset is sometimes tilting towards the protection of the environment and wildlife at all cost and sometimes allowing the exploitation in the name of development.

4) Corruption and ignorance of the law enforcement agencies lead to the flourishing of the trade rampant.

5) The lack of taxonomical data with the enforcement agencies leads to the illegally captured wildlife being passed on as legally captured or captive breeds under the law.

With both the nations varying in their geopolitical scenario, the level of protection accorded to the wildlife varies, making their life pretty erratic and gradually leading them to the verge of extinction.

\section{CONCLUSION}

The illegal wildlife trade in the last decade has increased drastically and taken the shape of a transnational crime operating around the globe. And the whole world has been divided into two distinct markets, one being the Source Country and the other are the Destination Countries. With the Destination countries are generally on the demand side, a remarkable plunge in the wildlife population is seen in the Source Countries as they are the supply countries. For instance, the African Nations are the major contributor to the illegal ivory trade industry in the Asian Nations, more specifically, China. This is not limited to the illegal wildlife trade only; rather, profits accrued from these illegal sectors are pushed into running drug cartels, funding armed conflicts and civil war in Source countries, which in turn allows them to carry on their trade, maintaining armed militia to control the border towns and bribing officials for the illegal trade activities. Apart from these, the impact can also be seen in the area of biodiversity also; the rampant poaching and illegal wildlife trade lead the endangered species to be forced to the brink of extinction. The scientists opine that it is a pivotal factor for spreading disease in humans and animals. To deter this ever-growing menace, the world community has come up with a number of umbrella legislation, e.g., CITES, which provides a framework for domestic legislation's molding. These legislations also provide a comprehensive list of the endangered species that are in desperate need of protection. But the rampant illegal wildlife trade activities and the depletion of the endangered species from the natural habitat are showing the dereliction in the implementation and the enforcement of these legislations.

The research was conducted by carrying out a detailed analysis of the specific provisions of the Wildlife Protection legislation of the two countries. Based on the analysis, it was found that the Chinese legislation is the most flexible one, which authorizes the commercial trade and utilization of the wildlife species along with their captive breeding for domestic as well as international consumption. But the increasing demand for wildlife drives the illegal poaching in the neighboring nations, India, which is then passed off through the border town as captive breed animals into China, in turn making them legal species for consumption. Another important observation and legislative loophole is the lack of implementation of the comprehensive list of protected wildlife as provided by the CITES. None of the legislation 
provided any or very limited protection to those in transit leading to the heavy poaching of these endangered species and forcing them to the brink of extinction.

After looking upon all these conclusions, there are some observations and suggestions which can be made. Since wildlife protection is driven by domestic legislation and each of the nations has its own set of legislation, there can't be straitjacket formulae for all the nations. As each disease has its own set of medicine, the same fundamental principle has to be applied here for the enforcement of the Wildlife Protection laws in the strictest sense, and each country has to find its own set of solutions for the issues that are being faced by it. But some of the general suggestions which would help in protecting the wildlife of the region are listed as below:

1) To implement the resolutions and decisions taken under the CITES at the earliest by its member parties.

2) To gather and analyze the intelligence related to organized illegal wildlife crime activities and to disseminate the same to State and Regional Enforcement Agencies for swift action to apprehend and arrest the criminals.

3) China should completely ban the commercial trade, exploitation, utilization and captive breeding of wildlife. And amend the legislation to inflict stringent punishments/penalties for those involved in the illegal wildlife trade.

4) Both nations should specify the procedural aspects of operating the scientific studies of wildlife.

5) Stricter implementation of enforcement mechanisms like shoot at sight orders for unauthorized access to protected areas and poaching activities. ${ }^{23}$

\section{REFERENCES}

\section{Jurnal}

[1] Challender, D. W., Harrop, S. R., \& MacMillan, D. C. (2015). Understanding markets to conserve trade-threatened species in CITES. Biological Conservation, 187, 249-259.

[2] Johnsingh, A. J. T., \& Williams, A. C. (1999). Elephant corridors in India: lessons for other elephant range countries. Oryx, 33(3), 210-214.

[3] Nagle, J. C. (1996). Why Chinese Wildlife Disappears as CITES Spreads. Geo. Int'l Envtl. L. Rev., 9, 435.

[4] Newton, D. J., \& Chan, J. (1998). South Africa's trade in southern African Succulent Plants. Traffic east/southern Africa.

[5] Reboredo, F. (2013). Socio-economic, environmental, and governance impacts of illegal logging. Environment Systems and Decisions, 33(2), 295-304.

\section{Online/World Wide Web, dll}

[6] Adopted at the Fourth Meeting of the Standing Committee of the Seventh National People's Congress and promulgated by Order No. 9 of the President of the People's Republic of China on November 8, 1988, and effective as of March 1, 1989.

[7] Africa Wildlife Foundation. 2015 World Wildlife Day Highlights Severity of Wildlife Crime. See https://www.awf.org/news/world-wildlifeday-highlights-severity-wildlifecrime (Last visited on 20th February 2020).

[8] https://www.loc.gov/law/foreign-news/article/china-new-wildlife-protection-law/

[9] Kaziranga Shoot Poachers At Sight Order: Govt Chooses To Be An Ostrich In Rhino Land". Firstpost. N.p., 2017.

\footnotetext{
23 "Kaziranga Shoot Poachers At Sight Order: Govt Chooses To Be An Ostrich In Rhino Land". Firstpost. N.p.,
} 2017. Web. 13 Apr. 2017. 